\title{
Notes and Discussions \\ Calvin and Hobbes, or, Hobbes as an Orthodox Christian
}

Three years ago, in the proceedings of an Italian conference on Hobbes and Spinoza, I published an article arguing that Hobbes was at best a deist, and most likely an atheist. ${ }^{1}$ In a recent book on Hobbes, A. P. Martinich devoted an appendix to criticizing that article, as part of his case that Hobbes is not merely a theist, but an orthodox Christian, and specifically, that he had "a strong commitment" to the Calvinist branch of the Church of England. ${ }^{2}$ It has been suggested that I respond to Martinich's rebuttal, and I think I should. Martinich's work is arguably the best available book of its kind.3 Pursuing the issues this book raises may help us to see why it is worth our while to be curious about the differences between the English text of Leviathan, first published in $165_{1}$, and the Latin text of that work, first published in 1668. This is a topic generally ignored in English-language discussions of Hobbes and one in which I have a special interest. 4

The great virtue of Martinich's book is that he is very precise about what his thesis

'See "'I Durst Not Write So Boldly' or, How to Read Hobbes' Theological-Political Treatise," in Hobbes e Spinoza, Atti del Convegno Internazionale, Urbino, I4-I7 ottobre, 1988, ed. by Daniela Bostrenghi, intro. by Emilia Giancotti (Napoli: Bibliopolis, 1992). By 'deist' I understand someone who believes in a personal God, but rejects divine revelation as a basis for religious belief. By an 'atheist' I understand someone who rejects the existence of any God.

${ }^{2}$ The Two Gods of "Leviathan" (Cambridge University Press, 1992), 1-2. Subsequent references to this book will cite page numbers in parentheses in the text.

3 I know no other sustained attempt to argue for such a bold thesis about Hobbes's religious views. Sharon Lloyd's Ideals as Interests in Hobbes's “Leviathan" (Cambridge University Press, 1992) is similar in certain respects: she assumes, as Martinich does, that Hobbes was a sincere Christian, who wished to make Christianity more acceptable to a modern age, and she argues that taking his Christian commitments seriously is essential to understanding his political philosophy. But she does not claim that Hobbes is orthodox $\left(17,112\right.$, and $\left.345^{-46}\right)$ or attempt to deal with the full range of Hobbes's positions on religious issues.

4 The edition of Leviathan I recently published with Hackett is the first in English to systematically translate variant passages from the Latin edition. In referring to Leviathan I cite passages by chapter and paragraph number, as given in my edition, which also has other material I believe will be useful (e.g., Hobbes's verse autobiography, excerpts from his prose autobiography and from Aubrey's biography, a glossary, annotation, and extensive indices). It was François Tricaud who paved the way here, by publishing a French translation which gave a very careful account of the differences between the English and Latin versions (Paris: Sirey, 1971). It is an embarrassment to English-language scholarship that we should need the French to show us how to treat one of our greatest philosophers. 
entails. A writer will count as an orthodox Christian if and only if he adheres to "the authoritative Christian creeds of the first four church councils," by which he means the Apostles' Creed and the Nicene Creed.5 There are some obviously good reasons for focussing on those creeds: they probably have wider acceptance among Christian churches than any others; the Church of England, to which Hobbes proclaimed his allegiance, requires acceptance of those creeds; ${ }^{6}$ and Hobbes himself would certainly have liked this definition of orthodoxy.7

There are also some less obviously good reasons for focussing on those creeds. One of the Hobbesian doctrines most apt to lead to charges of atheism is his materialism. He holds that the notion of an incorporeal substance is a contradiction ( $\mathrm{L}$ iv, 21 ), and this leads him-not to deny the existence of God and the human soul—but to say that they are material beings ( $\mathrm{L}$ xii, 7 , xliv, ${ }_{15}$, Latin Appendix iii, 6). By the seventeenth century a tradition had developed within Christianity of holding that God and the soul are immaterial beings. ${ }^{8}$ But the early church councils were primarily concerned with defining the church's position on the trinity, and they are silent on these metaphysical issues. As far as they are concerned, a Christian can be a materialist about both God and the soul (and some Christians have been).

Similarly with respect to the doctrine of immortality. One reason Christian theologians have often felt it necessary to insist on the immateriality of the soul has been that otherwise it might seem to be destructible. 9 In Leviathan Hobbes holds that in itself the

5 Those are the creeds he mentions $(2,6,61)$. Queen Elizabeth gave these councils special status when she established the High Commission, which was not to pronounce as heretical any doctrine not condemned by one of them. (Cf. Leviathan, Latin App. ii, 3o.) Perhaps the Apostles' Creed shouldn't count as the work of those councils; parts of it probably date as early as the second century; the present text probably dates from the eighth century (see Gordon Melton, Religious Creeds [Gale Research Co., 1988], 1). This description does, however, fit the Nicene Creed, whose earliest form dates from the first general council, held at Nicaea in 325 C.E., and whose present form was adopted somewhat later (according to Hobbes [English Works, IV, 40O401 , at the fourth council, held at Chalcedon in $45^{1}$ ).

${ }^{6}$ For example, the Thirty-Nine Articles of the Church of England identify those creeds as ones which "ought thoroughly to be received and believed, for they may be proved by most certain warrants of Holy Scripture" (Melton, Religious Creeds, 23). For Hobbes's declarations of allegiance to the Church of England, see my edition of Leviathan, lxiv-lxv, lxvii-lxviii.

7 Cf. his various discussions of heresy (e.g., in Leviathan, Latin App. ii, 30, $5^{2}$; in Behemoth, EW VI, 174-76; and in the "Historical Narration concerning Heresy," IV, 405-406).

${ }^{8}$ See Calvin, Institutes of the Christian Religion, I, xi, 2, on the immateriality of God, and I, xv, 2, 6, on the immateriality of the soul. This is also the doctrine of Aquinas (cf. Summa theologiae, I, qu. 3 , art. 1, and qu. 75 , art. 1).

9 Aquinas holds that the soul would be incorruptible even if it were composed of matter and form (I, qu. 75, art. 6). But Calvin seems to have thought the immateriality of the soul was essential to its immortality. Cf. Institutes, I, xv, 2. It's worth noting that Calvin's early theological treatise, Psychopannychia, was a defense of the immortality of the soul against the doctrine that the soul sleeps between the death of the body and the last judgment. Calvin associated this doctrine (wrongly, it seems) with the Anabaptists, and deferred publication of his treatise when friends pointed out that the position he was attacking was quite similar to one Luther held. See Willem Balke, Calvin and the Anabaptist Radicals (Grand Rapids: Eerdmans, 1981), 25-34, and Calvin, Opera quae supersunt omnia, V, 165-232, 1866 ed. (Corpus reformatorum, vol. XXXIII). 
soul is destructible; it is not naturally immortal ( $\mathrm{L}$ xxxviii, 4 ). Of course the God who made a living creature out of the dust by his word can, if he chooses, bring a dead carcass back to life and make the creature thus restored live forever ( $\mathrm{L} x \mathrm{xliv}, 15,32)$. But immortality is a possible consequence of divine grace, not a necessary consequence of man's nature. The early creeds, however, are not concerned to pronounce on the immortality of the soul. As far as they are concerned, a Christian can be a mortalist (and some Christians have been).

This theory leads naturally to a certain asymmetry in Hobbes's treatment of the fates of the saved and the damned. Our term 'grace' is derived from the Latin gratia, which signifies what is pleasing, or a favor or kindness done to someone, or a gift (cf. L xiv, 12). It seems reasonable enough to think of the immortality enjoyed by the elect in heaven as a gift, a kindness done them. Even if you believe that we are saved by works rather than faith, how could anyone, in a finite lifetime, behave well enough to deserve an eternal reward (cf. L xiv, 17)? It does not seem equally reasonable to say that it is by divine grace that the damned suffer eternal torment in hell. Some kindness! Perhaps as a result, Hobbes, so tough-minded on so many topics, is rather tender-minded on the punishment of the reprobate. Calvin had held that the wicked will suffer eternally, that they will "find no rest from being troubled and tossed by a terrible whirlwind, from feeling that they are being torn asunder by a hostile Deity, pierced and lanced by deadly darts, quaking at God's lightning bolt, and being crushed by the weight of his hand." ${ }^{\circ}$ Hobbes, however, contends that the wicked will get some rest, that God will keep them in hell for a while, suffering excruciating agonies, and then annihilate them in a second death:

It seemeth [OL: too] hard to say that God, who is the father of mercies, that doth in heaven and earth all that he will, that hath the hearts of all men in his disposing, that worketh in men both to do and to will, and without whose free gift a man hath neither inclination to good nor repentance of evil, should [OL: will to] punish men's transgressions without any end of time, and with all the extremity of torture that men can imagine, and more. (L xliv, 26; "OL" indicates an interpolation based on the Latin version of this passage.)

Hobbes does not deny that hell itself exists eternally as a place of punishment; he does deny that any particular wicked person will suffer there till eternity. And he recognizes that this implies that the human race must continue to propagate till eternity, in order to keep up the supply of sinners. ${ }^{11}$ By the seventeenth century a tradition had devel-

Hobbes' position in Leviathan is in some respects like Luther's, and Christian interpreters of Hobbes sometimes appeal to this fact to support reading his mortalism as acceptable Christian doctrine. But so far as I can see Hobbes does not attribute any existence to the soul between the death of the body and its resurrection, not even a sleeping one. Assuming that some continuity of substance is essential to personal identity, it is obscure why, on his view, we should identify the man who is resurrected with any previously existing person.

${ }^{10}$ Institutes, III, xxv, 12. I cite the Battles translation (Westminster Press, 1960).

${ }^{1 C}$ Cf. L xliv, 29. Martinich suggests that Hobbes is trying to come up with a "plausible, relatively humane and biblically based doctrine of hell" to compete with the view which had become standard in the seventeenth century. But he thinks the attempt a failure: "The idea of an infinite number of wicked people tortured for a finite period of time is not much more satisfying 
oped within Christianity of holding that the punishment of individual sinners is eternal. ${ }^{12}$ But the early creeds are in fact silent on this subject. So as far as they are concerned, a Christian can reject the doctrine of eternal punishment for the damned (and some Christians have).

Again, some readers of Leviathan have wondered whether Hobbes's moral views are really consistent with Christian teachings. Suppose we take Hobbes's enumeration of 19 laws of nature in chapters xiv and xv of Leviathan as an attempt to provide new foundations for an old morality. Martinich takes them that way (119), and I agree. The new foundation is a definition of 'law of nature' which makes it essential to a law of nature that it prescribe the means to self-preservation ( $\left.\mathrm{L} \mathrm{xiv,} 3 ; \mathrm{xv}, 4^{1}\right)$. Martinich makes the point that, though this might sound "offensive to pious ears," there is "nothing inherently non-Christian" about it. The gospels frequently offer the hope of heaven and the fear of hell as reasons for complying with their prescriptions (117-18). The real question, though, is whether the old morality Hobbes seeks to found is the morality of the gospels. Hobbes identifies his second law of nature with the Golden Rule (L xiv, 5 ); some have called this a bold act of appropriation, since the Golden Rule is normally thought to prescribe that we love our enemies and do good even to those who hate us, whereas Hobbes's second law prescribes that we be willing to lay down our right to all things, when others are so too. Perhaps Hobbes's insistence on reciprocity is incompatible with the spirit of the Golden Rule. ${ }^{13}$ Still, the early creeds have nothing to say about these issues; they make no prescriptions about conduct. So far as they are concerned, a Christian can do as she pleases to her enemies (and many Christians have).

Martinich has hit upon an ingenious argumentative strategy here, one whose potential even he does not seem to fully realize. For example, in L xxv, 2-3, Hobbes distinguishes between counsels and commands in the following way: both involve imperatives; in a command the only reason the commander offers for obedience is his own will; so the object of the command is some good to the commander; a counsellor will offer reasons based on the good of the person counselled. Now Martinich interprets Hobbes as a divine command theorist; the laws of nature oblige because they are divine commands $(87-99)$. In this respect he continues a line of interpretation begun by Taylor and Warrender. But he notices a problem with this view, one which I do not recall Taylor or Warrender addressing. If the laws of nature oblige because they are divine commands, and if a command is an imperative justified by the fact that obedience to it will benefit the commander, we seem to be driven to the conclusion that God

\footnotetext{
than the idea of a finite number tortured for an infinite period of time" (259-60). That seems right. It also seems doubtful that Hobbes's doctrine is consistent with the Christian doctrine of the last judgment. There was considerable discussion of (and discomfort with) the doctrine of hell in the seventeenth century. The classic study is D. P. Walker's The Decline of Hell (University of Chicago Press, 1974), which finds that Hobbes's views were beyond the pale.

${ }_{12}$ That this is Calvin's view is evident from the passage cited in the text. It was also Aquinas's view (Summa contra gentiles, III, ch. 144).

${ }_{13} \mathrm{Cf}$. The Elements of Law, I, xvii, 15 : "The sum of virtue is to be sociable with them that will be sociable, and formidable to them that will not."
} 
commands obedience to the laws of nature because our obedience will benefit him. Martinich maintains that an orthodox Christian will find this conclusion "obviously absurd" (132). And it would, perhaps, be an awkward conclusion for Hobbes to reach, given his contention that God has no ends (L xxxi, 13). But there is no reason, on Martinich's definition of orthodoxy, why drawing this conclusion would mark Hobbes as an unorthodox Christian. The early creeds are quite silent on the question whether God benefits from our obedience to his commands. So far as they are concerned, a Christian is free to believe what he likes on that subject.

The same holds for the question whether the imperatives of the gospel are commands or merely counsels. The reformers had tended to insist, against the authority of

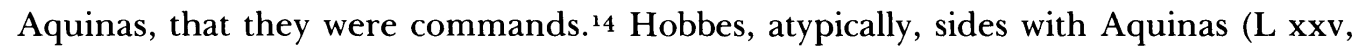
10; xliii, 5). But clearly this is an issue on which Christians may agree to differ. The early creeds are quite silent on the question whether the imperatives of Jesus impose a moral obligation on us or are merely good advice about the way to get to heaven. So far as they are concerned, a Christian is free to believe what she pleases about those imperatives.

What should we conclude from this? I think Professor Martinich has demonstrated, as fully as the nature of the case permits, that if we adopt his plausible definition of "orthodoxy," and if we take Hobbes at his word, Hobbes must have been an orthodox Christian. ${ }^{15}$ That is no small accomplishment. But perhaps it will be just as well to emphasize the exact wording of the concession just made. There will be some question, of course, about what the nature of the case permits. The more important question, though, is whether we should take Hobbes at his word. I had thought, when I wrote the article Martinich criticizes, that Hobbes was frequently ironic in his treatment of religion in Leviathan. Martinich contends that there are no undertones of irony in what Hobbes says about religion $(27-28)$, and that I am operating "with a defective idea of how to recognize irony" (351). He thinks I am inclined to see irony where none is intended.

I had attributed to Hobbes a particular form of irony which I called "suggestion by

${ }^{14}$ Cf. Calvin, Institutes, II, viii, 56-57, and Luther, On Secular Authority, ed. Harro Höpfl (Cambridge University Press), 4, 8, with Aquinas, Summa theologiae, I-II, qu. 108, art. 4, II-II, qu. 184 , art. 3 , qu. 186 .

${ }_{15}$ Cautious readers, however, might wish to suspend judgment about Martinich's more specific claim that Hobbes was a Calvinist. Apart from the differences already noted between Calvin and Hobbes-regarding the nature of God and of the soul, the immortality of the soul, the eternal punishment of the damned, and the status of Jesus's commands-there are several other areas of presumptive disagreement: on conscience (vii, 4), on $\sin (x x v i i, 1)$, on the authority of sovereigns to determine, within their dominions, which books contain the word of God (xxxiii, 1), on Jesus's belief in possession by demons (viii, 26), on the universality of the desire for power over others as an end in itself (xi, 2), on the reliability of the transmission of the law of Moses (xxxiii, 5 ), on the meaning of "the Kingdom of God" and the place in which the elect will enjoy eternal life (xxxv, 1, 11; xxxvii, 3; xliv, 4), on whether Mark 6:5 implies that Jesus was unable to perform miracles in his own country (xxxvii, 6), on whether the Pope is the Antichrist (xlii, 87-88), and on the necessity of works for salvation (xliii, 3). (For the contrasting passages in Calvin, see the annotation in my edition of Leviathan.) But perhaps these differences are unimportant by comparison with the similarities Martinich notes. 
disavowal." In this rhetorical device a writer presents a series of considerations which might reasonably lead his reader to draw a certain conclusion, but then denies that that conclusion follows. Consider, for example, Hobbes's treatment of prophecy, miracles, and scripture in L xxxii, xxxiii, xxxvi, and xxxvii. What he says on these matters might fairly be summarized as follows: miracles are important because they are a criterion of true prophecy (where a prophet is understood to be a messenger of God); one way you tell whether someone who claims to be a prophet is really a prophet is by seeing whether he (or she) can perform miracles (that's a necessary but not a sufficient condition); there is some difficulty, though, about applying this criterion; the crafty can easily persuade the gullible that they have performed a miracle when they have merely used their cunning (and perhaps confederates) to deceive; since being thought to be a prophet gives you great power over those who believe you to be a prophet, the unscrupulous have a strong incentive to try to deceive us; there are, of course, genuine miracles and genuine prophets; or at least, there were a long time ago (a time we know about only from ancient documents); but miracles don't happen any more; so nowadays we should be very wary of anyone who claims to perform miracles, and claims, on the basis of that performance, to be a messenger of God.

Now, does Hobbes intend his readers to draw a stronger conclusion than the one he in fact draws? Does he mean to cast doubt not only on present miracles, but also on those of the past (and, by implication, on the prophecy to which they testify and on the claim of scripture to be a divine revelation)? Martinich says no. Hobbes's intent is merely to discourage his contemporaries from accepting seventeenth-century claimants to prophecy, who might try to use the authority thus gained to disturb the political order (236). We should take Hobbes at his word when he says he accepts the occurrence of miracles and prophecies in the past. Literal interpretation is the default mode for the interpretation of texts; ironic interpretation is acceptable only when literal interpretation makes no sense (43). There is nothing in what he says on these subjects which has not been said by some Christian whose loyalty to the faith is unimpeachable (241-46). Martinich concedes that Hobbes's treatment of these issues did in fact contribute to a decline of belief in revealed religion. But he takes this to be an unintended consequence of Hobbes's writing as he did (345). Hobbes is neither a coward nor a liar, and it would have been a cowardly deception for him to have denied conclusions he really wanted people to draw, when he could have maintained his integrity by keeping silent (30-32).

I had not thought, of course, that Hobbes was a coward, for all that he likes to boast of his fearful nature. If he really held the views my article attributed to him, it would have been decidedly risky for him to publish them openly, given the penalties for dissent operating at the time. ${ }^{16}$ I had thought that he was rather daring to publish what he did. Nor had I thought that Hobbes was a liar. I didn't think that the use of irony quite constituted lying. The kind of irony I claimed to find in Leviathan places the responsibility for drawing the right conclusion on the reader. Only those will be de-

${ }^{16}$ I cited W. K. Jordan, The Development of Religious Toleration in England, from the Convention of the Long Parliament to the Restoration, I640-166o (Harvard University Press, 1938). 
ceived who don't have a good sense of where an argument ought to lead. Neither had I thought that Hobbes was a fool, who could not anticipate what the likely consequences of his actions would be. Silence on a subject so important, I thought, was not an attractive option to him, since he believed revealed religion to be dangerous, not only to the political order, but also to the progress of science.

Still, I think Martinich has raised a very significant issue here: how do you tell whether or not a text is ironic? I would grant that in interpreting texts we must operate with some kind of presumption in favor of literal interpretation. Does Martinich go too far when he says that an ironic interpretation is acceptable only if the literal interpretation makes no sense? I had held that Hobbes wrote with deliberate ambiguity, intending one set of readers to see the irreligious implications of his text, and another set to credit the disavowals of heterodox intent, ${ }^{17}$ so as to undermine religion without incurring punishment by the defenders of the faith. This strategy can work only if the literal interpretation makes some sense. So Martinich's rule will automatically exclude an ironic interpretation of any work seeking that complex effect. It might also exclude an ironic interpretation of Swift's “A Modest Proposal." Swift certainly took some pains to see that his proposal to market the children of the Irish poor as table delicacies made sense, not only from an economic, but even from a moral point of view. (The lives of the poor were so wretched that they themselves, when grown, would count it a blessing to have been sold for food at the age of one year!) As a result, some of his first readers took it to be a serious proposal and were horrified. But if we reject Martinich's rule, and if we wish to avoid reading modern unbelief into old books, which may be quite innocent of our corruption, what rule can we follow?

Some readers of Hobbes might reply by alleging that Hobbes frequently contradicts himself on religious topics, and that this is a marker of our need to be alert to hints of heresy. E.g.:

(1) in De cive xv, 14, and in Leviathan xxxi, 14, Hobbes affirms that it is manifest by natural reason that existence is to be attributed to God; in his Examination of Thomas White's "De Mundo," xxvi, 6, he contends that the authorities ought not to permit attempts to demonstrate the existence of God, because when ordinary men see that people who wish to believe in God's existence are unable to prove it, they will infer that God does not exist. ${ }^{18}$

(2) In Leviathan iii, 12, xxxi, 28, Hobbes affirms God's incomprehensibility; later in Leviathan (xlvi, 12) he criticizes the Jews for succumbing to the influence of Greek philosophy by incorporating the doctrine of God's incomprehensibility into their teaching.

(3) In the Appendix to the Latin Leviathan (i, 95) Hobbes acknowledges that the doctrine of God's incorporeality is affirmed in the articles of religion which define the Anglican faith, and that it must not be denied on pain of excommunication; in the same

${ }_{17}$ “"I Durst Not Write So Boldly'," 589-93.

${ }^{18}$ Hobbes wrote his Examination of Thomas White's “De Mundo" in 1642 , but it lay, unrecognized as a Hobbesian work, in the Bibliothèque nationale in Paris until after the Second World War. Jean Jacquot and Harold Whitmore Jones published an edition of the original Latin text in 1973 (Paris: Vrin), and Jones published an English translation in 1976 (Bradford University Press). 
Appendix (iii, 6) he affirms God's corporeality and defends the orthodoxy of that position by citing the authority of Tertullian.

(4) In Leviathan xxxviii, 4 , Hobbes denies that the soul is naturally immortal, and contends that its immortality is a matter of divine grace; in The Elements of Law (II, vi, 6) and De cive (xvii, 13) he affirms without qualification that the soul is immortal.

(5) In Leviathan xxxii, 5, Hobbes says that if someone claims to have had a direct revelation from God, and I question the claim, it's hard to see what argument he could give which would oblige me to believe him; in L xxvi, $4^{\circ}$, he had taken a stronger position: that no one can be sure that someone else has received a direct revelation from God unless he himself has received directly from God a revelation that the other person has had a direct revelation from God.

(6) In Leviathan xiv, 23, Hobbes claims that the only way to make a covenant with God is by the mediation of someone to whom God has spoken "either by revelation supernatural or by his lieutenants that govern under him and in his name"; in L xviii, 3 , he takes the stronger position that only the sovereign can mediate a covenant with God. ${ }^{19}$

Perhaps not all of these are strict contradictions. And certainly not all of them come from Leviathan itself. But collectively they do seem to demonstrate a tendency to vacillate on important religious issues, and some would say that this should make us suspicious.

To this Martinich can certainly reply, with justice, that authors often contradict themselves without being aware of it, and that Hobbes could not have intended all of these contradictions as hints about how to read Leviathan. Some of them are contradictions between Leviathan and works Hobbes never published (such as the Examination of Thomas White's "De Mundo"); some are contradictions between Leviathan and works Hobbes wrote many years earlier, when he may not even have planned to write Leviathan, and after which he may have changed his mind. Moreover, he might say, even where the contradiction occurs within Leviathan itself, Hobbes would not have expected his readers to notice contradictions which occur in passages from different chapters, which may be many pages apart. ${ }^{20}$

${ }_{19}$ Of course there is a quite general question in Hobbes as to whether it is possible for man to covenant with God, with or without a mediator. A covenant is a kind of contract (xiv, 11 ), and hence involves a transfer of rights (xiv, 9). But God's rights are supposed to be a consequence of his omnipotence $\left(\mathrm{xxxi}^{\mathrm{5}} \mathrm{)}\right)$. So it is unclear how he can either acquire or lay aside rights (cf. my annotation at xiv, 23).

Martinich is aware of this problem (cf. his 181-82, 291-94), though he does not define it in quite the way I have. He thinks Hobbes too was aware of the "tension" between God's sovereignty and his entering into covenants. But he apparently does not think Hobbes intended to suggest that tension to his readers. $\mathrm{L}$ xiv, 17 , and $\mathrm{xl}, 1$, are interesting here.

${ }^{20}$ In fact, this is what Martinich does say (55) about a contradiction Berman had alleged between L vi, 36 (which implies that God is capable of being imagined) and L xi, 25 (which implies that he is not). Of course Alexander Ross had noticed a similar difficulty about reconciling vi, $3^{6}$, with iii, 12 (in Leviathan Drawn Out with a Hook [London, 1653], 10). But in his case the contradictory passages were only 15 pages apart, not 25 ; so perhaps they are within the attention span Hobbes would have presumed. It is difficult to give a precise rule here. Clarendon showed 
Perhaps we ought not to put too much emphasis on Hobbes's vacillations regarding religious issues. What would really be helpful here would be more examples of suggestion by disavowal. Martinich ( $\left.35^{1}\right)$ complains that I offer only a few examples of this technique. ${ }^{21}$ Clearly the numbers matter in such cases, since the more evidence we have, the further we go towards establishing what the lawyers call a pattern of behavior. If we had more examples of the technique at work, particularly if some of them were quite clear cases, then it might be more reasonable to judge that Hobbes is using the technique in cases where there would otherwise be legitimate doubt about his intentions.

We might suppose we had such an example in Hobbes's discussion of angels in $\mathrm{L}$ xxxiv, 23-24, where the issue is whether or not we should regard angels as incorporeal substances. After an extended discussion of various Old and New Testament passages which tend to support a negative answer, Hobbes concludes by reporting that, though philosophical and theological considerations had inclined him to reject angels as "apparitions of the fancy," numerous (unspecified) passages in the New Testament had extorted from him a confession of the weakness of his reason and an admission of their reality. On the literal reading xxxiv, 24, is inconsistent with xlv, 31, and App. iii, 1518. And the attitude Hobbes displays toward reason in xxxiv, 24, comes somewhat oddly from an author who could write that men set themselves against reason as often as reason is against them $(\mathrm{xi}, 21)$. Still, Martinich takes what Hobbes says at face value here $\left(\mathbf{2 5} \mathbf{0}^{\mathbf{0}}-\mathbf{5}^{2}\right)$; so I suppose this must be counted as a doubtful case.

But what about Hobbes's treatment of the trinity? Given the centrality of the early creeds to Martinich's definition of orthodoxy, and the centrality of the doctrine of the trinity to those creeds, this is a case of more than incidental interest. The basic facts about Hobbes's way of dealing with the trinity will be well enough known to Hobbes scholars. But the topic has not been at the forefront of recent discussions, so a brief review may be in order. In L, xvi, Hobbes defines a person as one "whose words or actions are considered either as his own, or as representing the words or actions of another man, or of any other thing to whom they are attributed, whether truly or by fiction" (xvi, 1). The primary application of this doctrine is political: a multitude of men become one person when, by the consent of all, some man or assembly represents them (xvi, 13). But Hobbes also uses his theory to explain how one God can be three persons: God is said to be one person when represented by Moses, another when represented by Jesus, and a third when represented by the apostles. ${ }^{22}$

remarkable alertness in noting the contradiction between xxxii, 7 (the Egyptian sorcerers performed great miracles) and xxxvii, 9-10 (no created spirit can perform a miracle). These passages were no fewer than $3^{8}$ pages apart.

${ }^{21}$ Martinich does not actually challenge any of the Hobbesian examples I discussed, though he does discuss and reject an example I had drawn from Elizabeth Anscombe, as (I foolishly imagined) a clear illustration of the technique at work. Perhaps I might have chosen other examples. Descartes's discussion of appeals to scripture in the letter he wrote dedicating his Meditations to the Faculty of Theology at the Sorbonne comes to mind (Adam and Tannery, VII, 1-2). But I suspect that any historical example I used might be open to challenge, since part of the point of this rhetorical device is to permit doubt about the author's intentions.

${ }^{22}$ In point of fact, Hobbes gives different accounts of who God's representatives on earth are. The least generous mentions only Moses, Jesus, and the apostles. Cf. xvi, 12. But in other places 
From an orthodox Christian standpoint, this theory has certain disadvantages. It apparently makes Moses and the apostles (and all the rest) coequal with Jesus as persons of the trinity, whereas the intent of the doctrine of the trinity would seem to be to give Jesus a status greater than that possessed by any mere human. Prima facie, Hobbes's theory denies the eternity of the three persons of the trinity. And since the third representative (and in some versions of the theory, the first also) is a multitude with no collective decision-making procedure, it is hard to see why there are only three persons in this trinity. These problems did not go unnoticed by Hobbes's contemporaries, and they seem sufficiently obvious that you would think a theologically sophisticated author would have anticipated the negative reaction of the orthodox. ${ }^{23}$ Martinich acknowledges that Hobbes's interpretation of the trinity is not free from problems (207). But he thinks they are problems inherent in any sincere attempt to explain a doctrine which may be inconsistent (and which, if consistent, is hard to show to be consistent). Hobbes was trying, in good faith, to make the doctrine of the trinity both coherent and orthodox. He failed, but he could hardly have succeeded. His failure is not to be read as an indication of underhanded motives, as if he were saying "the only way you can make this doctrine coherent is to make it radically unorthodox."

Some readers may find it disappointing that Martinich does not say more about what happened to Hobbes's theory of the trinity in the Latin edition of Leviathan. Most scholars are aware that Hobbes acknowledged defects in the theory of the English edition and dropped it from the Latin editions. ${ }^{24}$ But many students of Hobbes are not aware of what replaced it. It is a pity that Martinich does not discuss the way Hobbes responded to criticism on this point. In some places, of course, Hobbes just deleted the theory of the English Leviathan without putting anything in its place (xlii, 3). Sometimes he just replaced the discarded theory with the treatment of the trinity in the Anglican catechism (xvi, 12; Appendix iii, 1 1-14). But in ch. i of the Latin Appendix, which has no analogue in the English Leviathan, Hobbes engages in an extended analysis of the Nicene Creed, with particular emphasis on its formulation of the doctrine of the trinity. I will not suggest, as some might wish to do, that Professor Martinich has not done his homework here. But it does seem plausible to think that a conscientious

\footnotetext{
he adds the successors of Moses (the high priests and kings of Judah) and the successors of the apostles "to this day" (cf. xxxiii, 2o). I assume that the successors of the apostles include the popes (cf. xliv, 32) and I suppose they also include the kings and queens of England from the time of Henry VIII, since they are the heads of the church in their domains.

${ }_{23}$ For Bramhall, see Hobbes, EW IV, 314-15. For Clarendon, see $A$ Brief View and Survey of the dangerous and pernicious errors to Church and State, in Mr. Hobbes' Book Entitled "Leviathan" (Oxford,

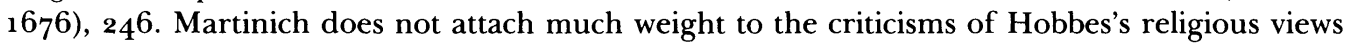
made by his contemporaries, on the grounds that most of Hobbes's contemporary critics were Arminian Anglicans, who would use any stick to beat a Calvinist, or uncompromising royalists, who didn't like Hobbes's contractarian rejection of divine right theory (35). This makes it rather important for him to establish Hobbes's Calvinism.

${ }^{24}$ See his answer to Bramhall, EW IV, $316-17$. Alterations in response to criticism of his treatment of the trinity occur not only in xvi, 12 and xlii, 3 , but also in xxix, 16; xxxiii, 20; xl, 14; xli, 9; xlii, 18 ; xliv, 32 .
} 
scholar, defending the thesis Martinich defends, might have felt an obligation to say something about this text.

We might suppose that Martinich thought he had covered the matter by what he said about Hobbes's analysis of the Nicene Creed in the "Historical Narration concerning Heresy" (EW IV, 392-402). But it seems that in fact he didn't think that. Here's what he says, omitting only the page references: "The chief theological purpose of the early creeds was to insist that there is only one God, who is three persons. And the chief political purpose of them was peace. ... After delivering a learned disquisition on the meaning of the Apostles' Creed [sic] relative to the various heresies it was meant to counteract, Hobbes discusses the history of heresy in England" (6o-61). There seems to be an unfortunate confusion here about just which creed is up for discussion in the "Historical Narration": the Apostles' Creed or the Nicene. ${ }^{25}$ The two creeds are quite similar, of course, and Hobbes does mention the Apostles' Creed as he is introducing his discussion of the Nicene Creed. But the two creeds do have differences which appear to have been important to Hobbes, and in the "Historical Narration" it is the Nicene Creed, not that attributed to the Apostles, on which Hobbes focuses. A brief consideration of the Latin Appendix may help to explain why.

The Appendix is written as a dialogue between two parties, designated as " $\mathrm{A}$ " and "B." In ch. i A starts matters off abruptly by asking B to explain the Nicene Creed to him, "not so that I may grasp these matters in my mind, but so that I may understand the words of the faith in such a way that they are consistent [consentanea] with Sacred Scripture" (App. i, 1). This is the translation I gave in my recent edition of Leviathan. Perhaps the translation of consentanea is tendentious. The point of A's question, it might be said, is not to demand explanation of a prima facie inconsistency between the creed and scripture, but to demand a proof that the creed follows from scripture, in accordance with article 20 of the Anglican Church. ${ }^{26}$ Arguably, a better translation would be "that they agree with Sacred Scripture," suggesting simply a need to show that there is good scriptural authority for each element of the creed. ${ }^{27}$

Suppose this is right. ${ }^{28}$ It will be sufficient here if we assume that the prima facie problem with the creed is merely that there is not good scriptural authority for all of it. Twice in the Latin Leviathan Hobbes says otherwise. In the Latin version of ch. xlvi Hobbes adds several paragraphs to the English version, giving a brief account of early church history. In this section he writes that the Nicene Council condemned "not only

${ }^{25}$ This is evidently not a casual slip, since it also occurs on p. 2, where Martinich says that in the "Historical Narration" Hobbes "approvingly explicates the Apostles' Creed."

${ }^{26} \mathrm{Cf}$. Appendix, i, 96: "In article 20 it is said that the church ought not to ordain anything to be believed which cannot be deduced from Sacred Scriptures." (Actually, Hobbes's version of article 20 would be more apt as a paraphrase of article 6.)

${ }_{27}$ Cf. the translation of the Appendix by George Wright, published (with extensive annotation and commentary) in Interpretation 18 (1991): 323-413.

${ }^{28} \mathrm{I}$ 'm not sure it is. Cf. A's comment in i, 63: "So far you have explained the doctrine of the Nicene Creed in such a way that it does not seem to me that you have shaken the Christian faith at all; instead you have strengthened it, though in your own way." A curious reader might wonder why A seems to think there is a prima facie conflict between the creed and the Christian faith, and whether B has really explained that conflict in a way which ought to satisfy A. 
Arius, but also all heresies which had arisen since the birth of Christ, summing up briefly the orthodox faith in the creed called Nicene, taken from Scripture itself, with no admixture of Greek philosophy at all" (xlvi [OL], 10). Similarly, in the Appendix, A notes that "almost all those theologians who published explanations of the Nicene creed use definitions taken from the logic and metaphysics of Aristotle, when they ought to have proven the holy Trinity from Sacred Scripture alone ...," and then expresses his amazement that "the Nicene Fathers, so many of whom were philosophers, did not bring into the creed itself those terms of art which they used in their explanations" (i, 9o). Is there any ground to regard these statements as ironic? It is false-manifestly false, I would have thought-that the Nicene Creed contains no terms of art derived from Greek philosophy. Specifically, in defining the relation between God the Son and God the Father, it says that Jesus was "of the substance [ex tes ousias] of the Father," and "of one substance [homoousion] with the Father." When someone says something manifestly false, we often take that as a sign of an ironic utterance. ${ }^{29}$ There may be a special danger in reading historical texts, that we will project our own ideas about truth and falsity onto an earlier author, inferring irony where all that is present is error. But it seems unlikely, in this instance, that Hobbes did not know what we know. The use of the term homoousios (one feature which distinguishes the Nicene from the less metaphysical Apostles' Creed) was also one of the most controversial features of that creed. $3^{\circ}$ The council majority had wanted to adhere only to scriptural language, but embraced the term homoousios when it became apparent that they could not distinguish themselves from the Arians without departing from scriptural language. ${ }^{3^{1}}$ Hobbes seems to be well-informed about that history. Here's what he says about it in the "Historical Narration":

For this word, of one substance, in Latin consubstantialis, but in Greek homoousios, that is, of one essence, was put as a touchstone to discern an Arian from a Catholic; and much ado there was about it. Constantine himself, at the passing of this creed, took notice of it for a hard word, but yet approved of it, saying that in a divine mystery it was fit to use divina et arcana verba, that is, divine words and hidden from human understandingcalling that word homoousios divine, not because it was in the divine Scripture (for it is not there), but because it was to him arcanum, that is, not sufficiently understood. And in this again $3^{2}$ appeared the indifferency of the Emperor, and that he had for his end, in the

${ }^{29}$ See, for example, the analysis of irony in Robert Fogelin's Figuratively Speaking (Yale University Press, 1988), 5-23.

$3^{\circ}$ In Appendix i, 17, A calls it "that great article which in the ancient church produced so many disturbances, exiles and killings."

${ }^{31}$ See Jaroslav Pelikan, The Christian Tradition, Vol. I: The Emergence of the Catholic Tradition (Ioo-6oo) (University of Chicago Press, 1971), 202.

${ }^{32}$ Hobbes also accuses Constantine of "a greater indifferency than would in these days be approved of" for having agreed to enforce adherence to whatever articles of faith the bishops assembled at the Council of Nicaea agreed on (EW IV, 392). As Hobbes notes in the Latin Appendix (ii, 3o), the situation of the Anglican Church under Elizabeth was like that of the Roman Church under Constantine. (William Haugaard's Elizabeth and the English Reformation [Cambridge University Press, 1968], which generally defends Elizabeth against charges of indifference in matters of religion, is interesting here. See $236-37$.) 
calling of the Synod, not so much the truth, as the uniformity of doctrine, and peace of his people that depended on it. The cause of the obscurity of this word, homoousios, proceeded chiefly from the difference between the Greek and Roman dialect in the philosophy of the Peripatetics. (EW IV, 393, Hobbes's emphasis)

It might be suggested that when Hobbes wrote the Latin Appendix, which was published in 1668, he was not aware that homoousios was not a scriptural term, and that he discovered this between the composition of that work and that of the "Historical Narration," which was not published until 1680. But in the Latin Leviathan Hobbes does seem to be generally well-informed about the history of the early church councils (see, for example, xlvi, 9-11, App. i, 14; ii, 20, 24, 52; iii, 6); and to explain the orthodox doctrine of the trinity, he apparently thinks it necessary to engage in an extended discourse on the technical terms of Greek philosophy (i, 59-91).

If we read as ironic Hobbes's denials that the Nicene Creed contains an admixture of Greek philosophy, what follows? Hobbes regularly professes adherence to the Reformation principle that Scripture alone is the test of what a Christian must believe. Here's a nice passage from the Latin Appendix:

I shall really say nothing about this [the immortality of the soul], except what I find said clearly and without any ambiguity in Scripture, which no other text plainly contradicts. You, of course, along with nearly everyone else, take from the philosophers the doctrine that the human soul cannot perish. But I, having now the Sacred Scriptures, do not desire the philosophers as my masters. Nevertheless, if you show me some passage from Sacred Scripture where another immortality is attributed to the human soul besides that which is given to men under the name of eternal life, I too shall think with the philosophers. $(i, 46)$

Martinich appeals to similar passages in the English Leviathan to support his contention that Hobbes is a good reformed theologian (e.g., on 66). But suppose Hobbes's insistence on the sola Scriptura principle, combined with his repeated affirmations (of the manifestly false claim) that the Nicene Creed is untainted by Greek philosophy, is a way of calling our attention to the fact that the Creed itself fails the fundamental test of reformation theology. If he is serious about his adherence to the sola Scriptura principle, he could not be, by Martinich's definition of orthodoxy, an orthodox Christian. On this hypothesis he would be raising, delicately, a dilemma for reformed Christians generally: if you permit Church tradition and the decisions of Church councils to define the Christian faith, it may be difficult to reject such Roman Catholic extravagances as the doctrine of purgatory; if you insist that Christian doctrine is limited to what can be read in scripture or proven from scripture, you may have to sacrifice a doctrine as dear to your hearts as the trinity. And he would be suggesting a particular problem for the Anglican "middle way," which (in what might appear to be a spirit of unprincipled political compromise) accepted exactly four general church councils as valid: the Thirty-Nine Articles which define the basic teaching of the Anglican Church are inconsistent, requiring believers to accept the Nicene Creed, and at the same time denying the Church permission to require any doctrine for which there is not adequate scriptural authority. 
Hobbes comes back to this issue in the third chapter of the Latin Appendix, where he is replying to objections made against the English Leviathan, among them one which challenges him to explain how his denial of incorporeal substances is compatible with his affirmation of the existence of God. He takes the opportunity to argue for the orthodoxy of his view that God is corporeal: "Not even the Nicene Council defined it as an article of faith that God is incorporeal. The fathers who were present, however, thought that God was incorporeal (whether they all thought this I don't know). And Constantine himself approved the term homoousios, i.e., coessential, because it seemed to him to follow from that term that God is incorporeal. Nevertheless, they did not want to introduce the term incorporeal, which is not in Sacred Scripture, into the creed" (iii, 6). There is more at stake here than just the question of God's corporeality. Specifically, this passage does raise the question: how, if the fathers rejected the term incorporeal because it was nonscriptural, could they in consistency approve the equally nonscriptural term homoousios?

I presume Martinich would reply that an ironic reading of Hobbes on the trinity attributes too much subtlety to him. It may be reasonable for us to draw these conclusions from what Hobbes says. But it does not follow that Hobbes intended us to draw them. To suppose that Hobbes could see that these conclusions followed from what he said, or could see that readers might reasonably think they did, is to suppose that Hobbes was as perceptive as we are. As Martinich says, "A general problem with Straussian interpretations is that they overestimate the abilities of philosophers." 33 We have no right to suppose that Hobbes could see what we see, particularly when doing so implies attributing to Hobbes the moral flaw of pretending to be an orthodox Christian when he was not. Hobbes is as entitled to a presumption of innocence as anyone else accused of unorthodoxy. Unless it is proven beyond a reasonable doubt that Hobbes is guilty, we must acquit him.

What shall we conclude from all of this? I believe that in that earlier essay of mine I was, as Philo might say, less cautious on the subject of Hobbes's religion than I am accustomed to be, and than the subject deserves. Perhaps I was unduly influenced by a comment Aubrey reports Edmund Waller34 as having made, when Aubrey asked him, after Hobbes's death, to write some verses in praise of their friend. Waller declined, saying that he was afraid of the churchmen, and that "what was chiefly to be taken notice of in his elegy was that he, being but one, and a private person, pulled down all the churches, dispelled the mists of ignorance, and laid open their priestcraft" (lxxi in

33 I acknowledge that my interpretation of Hobbes is Straussian (as is my interpretation of Spinoza). But I am not a Straussian in general. Regarding Descartes, see my exchange with Hiram Caton ("The Problem of Professor Caton's Sincerity," Independent Journal of Philosophy 5/6: 10-15). Regarding Leibniz, see "The Root of Contingency," in Leibniz, A Collection of Critical Essays, ed. Harry Frankfurt (Anchor, 1972), 69-97.

34 For an account of the relationship between Hobbes and Waller, see The Correspondence of Thomas Hobbes, ed. Noel Malcolm (Oxford University Press, 1994), II: 913-15. In his life of Hobbes, Aubrey reports that it was Waller who sent Spinoza's Theological-Political Treatise to Lord Devonshire, asking him to solicit Hobbes's opinion of it, thereby prompting Hobbes to make the remark which was the subject of the essay Martinich criticizes: "He has outthrown me a bar's length; I durst not write so boldly." Cf. my edition of Leviathan, lxviii. 
my edition of Leviathan). Martinich's book has persuaded me that it is not only Hobbes's professed enemies who have misunderstood his philosophy, but that even those who think themselves his friends are capable of profoundly misreading his intentions. But which of Hobbes's friends has him right, Martinich or Waller?35

EDWIN CURLEY

University of Michigan, Ann Arbor

35 For helpful suggestions about the earlier drafts of this paper I am indebted to Stephen Darwall, Louis Loeb, and Quentin Skinner. I pursue the issues of this paper further in an article entitled "Religion and Morality in Hobbes," which I believe will appear in the proceedings of the conference held in memory of Greg Kavka, in Irvine, February 1995. 